\title{
Nitric Oxide Regulates the Expression of Vasoconstrictors and Growth Factors by Vascular Endothelium under both Normoxia and Hypoxia
}

\author{
Stella Kourembanas, ${ }^{\star}$ Lynda P. McQuillan, ${ }^{\star}$ Gordon K. Leung, * and Douglas V. Faller* \\ *Joint Program in Neonatology, Harvard Medical School, Boston, Massachusetts 02115; and the ${ }^{\ddagger}$ Cancer Research Center, \\ Boston University Medical Center, Boston, Massachusetts 02118
}

\begin{abstract}
The mechanisms by which hypoxia causes vasoconstriction in vivo are not known. Accumulating evidence implicates the endothelium as a key regulator of vascular tone. Hypoxia induces the expression and secretion of endothelin-1 (ET-1), a potent vasoconstrictor in cultured human endothelial cells. We report here that nitric oxide (NO), an endothelial-derived relaxing factor, modifies this induction of ET-1. Whereas low oxygen tension ( $\mathrm{PO}_{2}=20-30$ Torr $)$ increases ET-1 expression four- to eightfold above that seen at normal oxygen tension $\left(\mathrm{Po}_{2}=150\right.$ Torr), sodium nitroprusside, which releases NO, suppresses this effect. This inhibition of hypoxia-induced ET-1 expression occurs within the first hour of exposure of cells to sodium nitroprusside. Moreover, when the endogenous constitutive levels of NO made by endothelial cells are suppressed using $\mathbf{N}$ - $\omega$-nitroL-arginine, a potent competitive inhibitor of NO synthase, the baseline levels of ET-1 produced in normoxic environments are increased three- to fourfold. The effects of hypoxia and the NO synthase inhibitor on ET-1 expression are additive. The regulation of ET-1 production by NO appears to be at the level of transcription. Similar effects of NO were observed on the expression of the PDGF-B chain gene. PDGF-B expression was suppressed by NO in a hypoxic environment and induced by $\mathrm{N}$ - $\omega$-nitro-L-arginine in both normoxic and hypoxic environments. These findings suggest that in addition to its role as a vasodilator, NO may also influence vascular tone via the regulated reciprocal production of ET-1 and PDGF-B in the vasculature. (J. Clin. Invest. 1993. 92:99-104.) Key words: hypoxia • nitric oxide • endothelin • umbilical vein • platelet-derived growth factor-B
\end{abstract}

\section{Introduction}

Endothelial cells serve a key role in the local regulation of blood vessel tone via the release of vasoactive agents controlling smooth muscle cell proliferation and contractility. They are known to release both vasoconstrictors such as endothelin-1 $(\text { ET-1 })^{1}$ (1) and PDGF (2) and vasodilators such as endothelial-derived nitric oxide (NO) (3) in response to local and circulating factors. In fact, the presence of an intact endothelium

Address correspondence to Stella Kourembanas, M.D., Joint Program in Neonatology, Children's Hospital, 300 Longwood Avenue, Boston, MA 02115.

Received for publication 18 November 1992 and in revised form 16 February 1993.

J. Clin. Invest.

(c) The American Society for Clinical Investigation, Inc.

0021-9738/93/07/99/06 \$2.00

Volume 92, July 1993, 99-104 is necessary for agents such as bradykinin and acetylcholine to cause vascular smooth muscle cell relaxation (4).

NO or some closely related molecule is formed by the vascular endothelial cells from the guanidino group of $\mathrm{L}$-arginine which is converted to citrulline by the enzyme nitric oxide synthase (5). Endothelial-derived NO is thought to mediate vasorelaxation in vivo by diffusing from the endothelial cells to the smooth muscle cells, and activating soluble guanylate cyclase which results in elevated levels of intracellular cGMP. $\mathrm{L}$-arginine analogues have been described as inhibitors of $\mathrm{NO}$ generation (6). Infusions of such inhibitors into humans results in significant vasoconstriction, suggesting that some constitutive release of NO maintains the vasculature in a partially dilated state (6).

ET-1 is a 21 -amino acid peptide with potent vasoconstrictor properties (7). The human ET-1 is derived from a 212 amino acid peptide, preproET-1, via a 38-amino acid intermediate called big endothelin. PreproET-1 mRNA is expressed by human endothelial cells from a variety of vascular beds and is regulated by factors such as transforming growth factor $\beta$, phorbol esters, shear stress (1), and thrombin (8). Due to its vasoconstrictive properties, ET-1 has potent cardiovascular, pulmonary, and renal actions and may play a pathophysiologic role in a number of conditions including myocardial infarction (9), renal disease (10), and pulmonary hypertension (11).

We have recently reported that hypoxia strongly upregulates the transcriptional rate of the ET-1 gene in human umbilical vein endothelial cells, resulting in a four- to eightfold increase in ET-1 protein secretion (12). In addition, we have shown that hypoxia increases the transcriptional rate of the PDGF-B chain gene in human endothelial cells (13). PDGF is a dimer composed of two peptides, $\mathrm{A}$ and $\mathrm{B}$, that are products of two independently regulated genes (13). The PDGF-BB dimer in particular is a potent mitogen and chemoattractant for vascular smooth muscle cells and has vasoconstrictor activity (14). It is known that chronic hypoxia results in smooth muscle cell hyperplasia in the microvasculature of the lung and that acute hypoxia causes vasoconstriction of the pulmonary blood vessels. Agents such as ET-1 and PDGF that are induced by hypoxia might mediate some of these hypoxia-induced changes in the pulmonary vasculature.

Endothelial cells, therefore, can regulate vascular tone by releasing both vasoconstrictors such as ET-1 and PDGF, and vasodilators like NO. In this manner, normal tone would be maintained by a balance of these two types of vasoactive mediators, possibly through feedback loop mechanisms. We therefore investigated whether endogenous or exogenous variations

1. Abbreviations used in this paper: bFGF, basic fibroblast growth factor; CO, carbon monoxide; ET-1, endothelin-1; HUVE, human umbilical vein endothelial cells; L-NNA, $N$ - $\omega$-nitro-L-arginine; NO, nitric oxide; SNP, sodium nitroprusside. 
in levels of NO could modify the increases in endothelin or PDGF production by vascular endothelial cells in response to hypoxia.

\section{Methods}

Cell culture. Primary cultures of human umbilical vein endothelial cells (HUVE) were subcultured on gelatin-coated plates in the presence of heparin $(15 \mathrm{U} / \mathrm{ml})$ and endothelial cell growth supplement ( $2.5 \mathrm{mg} / 100 \mathrm{ml}$ media) (Sigma Chemical Co., St. Louis, MO), in M199 medium (Gibco Laboratories, Grand Island, NY) with 20\% fetal calf serum (Hyclone Laboratories, Logan, UT) at $37^{\circ} \mathrm{C}, 5 \% \mathrm{CO}_{2}$ in a humidified incubator. Cells were passaged by trypsinization with $0.025 \%$ trypsin/EDTA (Gibco Laboratories) every 3-4 d. Endothelial cells at confluence between passages 6 and 10 were exposed to low oxygen tensions in air-tight chambers flushed with preanalyzed gas mixtures and kept at $37^{\circ} \mathrm{C}$.

The desired oxygen mixture was preanalyzed (Northeast Air and Gas, Inc., Manchester, NH) and infused into air-tight incubators with inflow and outflow valves (Billups-Rothenberg Inc., Del Mar, CA) at a flow rate of $3 \mathrm{liter} / \mathrm{min}$ for $15 \mathrm{~min}$ per $\mathrm{d}$. We have previously found a steady drop in $\mathrm{Po}_{2}$ from 150 Torr to 60 Torr by $6 \mathrm{~h}$ of hypoxia using a gas mixture of $95 \% \mathrm{~N}_{2} / 5 \% \mathrm{CO}_{2}\left(0 \% \mathrm{O}_{2}\right.$ environment $)(12)$. The $\mathrm{PO}_{2}$ in the media reached a level of 20 Torr after $12 \mathrm{~h}$ and remained so throughout the duration of the incubation period (up to $3 \mathrm{~d}$ ). When $1 \%$ $\mathrm{O}_{2}$ was infused with $94 \% \mathrm{~N}_{2} / 5 \% \mathrm{CO}_{2}$ gas mixture, the lowest $\mathrm{PO}_{2}$ reached in the media was 30 Torr. We have found the regulation of ET-1 and PDGF-B genes to occur between this narrow range of oxygen tension (0-1\% $\mathrm{O}_{2}$ environment corresponding to a $\mathrm{PO}_{2}$ of 20-30 Torr). Therefore, either 0 or $1 \% \mathrm{O}_{2}$ environments are used as indicated in each figure to attain a hypoxic atmosphere.

Reagents. $N$ - $\omega$-nitro-L-arginine (L-NNA) was purchased from Sigma Chemical Co. and sodium nitroprusside from Elkins-Sorin, Inc. (Cherry Hill, NJ).

RNA analysis. Total cellular RNA was prepared by the method of Chirgwin et al. (15) from endothelial cells exposed to various oxygen tensions at confluence. Total RNA ( $15 \mu \mathrm{g} /$ lane $)$ was separated by electrophoresis on $1 \%$ agarose gels containing formaldehyde and transferred to nitrocellulose membranes by blotting. The filters were hybridized with a $1,200-b p,{ }^{32} \mathrm{P}$-labeled cDNA probe specific for the human preproET-1 gene (16). The probe for the PDGF-B chain gene was the 1,300-bp PstI fragment of Simian Sarcoma Virus Clone C60 (17) encoding the $v$-sis oncogene. The actin probe was the 800 -bp PstI fragment of the mouse $\beta$-actin gene. Hybridization conditions were as previously described (13). For quantitation, transcript levels of preproET1 and PDGF-B were normalized after densitometry to the levels of actin transcripts, which did not change under the various oxygen environments.

Nuclear run-off analysis. Confluent cultures of endothelial cells were exposed to $21 \%$ oxygen for $48 \mathrm{~h}$ in the presence or absence of 2.5 mM L-NNA. At the end of the incubation, nuclei were isolated as previously described (13). Aliquots of nuclear suspension were incubated with $0.5 \mathrm{mM}$ each of CTP, ATP, and GTP and $250 \mu \mathrm{Ci}$ of $\alpha-{ }^{32} \mathrm{P}$ labeled UTP ( 3,000 Ci/mmol) (New England Nuclear, Boston, MA). The samples were phenol/chloroform extracted, precipitated, and resuspended at equal cpm/ $\mathrm{ml}$ in hybridization buffer $\left(10-20 \times 10^{6} \mathrm{cpm} /\right.$ $\mathrm{ml})$. Hybridization to denatured probes $(1 \mu \mathrm{g})$ dot-blotted on nitrocellulose filters was performed at $40^{\circ} \mathrm{C}$ for $3 \mathrm{~d}$ in the presence of $50 \%$ formamide. cDNA probes for the preproET-1, PDGF-B, and basic fibroblast growth factor (bFGF) genes were used.

Measurements of ET-1. Confluent endothelial cells in triplicate 60$\mathrm{mm}$ plates were washed, refed, and exposed to $0 \% \mathrm{O}_{2}$ alone, or $0 \% \mathrm{O}_{2}$ plus $1 \mathrm{mM}$ sodium nitroprusside (SNP) or $0 \% \mathrm{O}_{2}+2.5 \mathrm{mM}$ L-NNA for $24 \mathrm{~h}$. A parallel culture containing $1 \mathrm{mM} \mathrm{SNP}$ or $2.5 \mathrm{mM}$ L-NNA was maintained in $21 \%$ oxygen. The conditioned media were collected, spun to remove cells, and kept frozen at $-20^{\circ} \mathrm{C}$ until assay. ET-1 pep- tide was measured using a radioimmunoassay kit (Amersham Corp., Arlington Heights, IL) with a detection limit of $10^{-15} \mathrm{~g} / \mathrm{ml}$. The antiserum used in this assay does not cross-react with big endothelin. ET-1 production is shown as ET-1 concentration in $3 \mathrm{ml}$ of medium produced/time.

\section{Results}

Inhibition of NO synthesis increases preproET-1 and PDGF-B $m R N A$ levels. Since endothelial cells are a major source of NO production in the body, we investigated whether the endogenous levels of NO produced by these cells could modify the baseline and hypoxia-induced amounts of preproET-1 mRNA expressed by these cells. Endothelial cells were exposed to a hypoxic atmosphere with a $\mathrm{Po}_{2}=30 \mathrm{mmHg}\left(1 \% \mathrm{O}_{2}\right)$ or normoxic atmosphere with a $\mathrm{PO}_{2}=150 \mathrm{mmHg}\left(21 \% \mathrm{O}_{2}\right)$ for $48 \mathrm{~h}$ in the presence or absence of $2.5 \mathrm{mM} \mathrm{L}-\mathrm{NNA}$, a potent competitive inhibitor of the enzyme NO synthase. In the presence of this inhibitor in a normoxic environment, the levels of preproET-1 mRNA were elevated three- to fourfold compared to levels in cells not exposed to the inhibitor. These elevated levels were similar to those in cells which had been exposed to a hypoxic environment for the same time interval (Fig. $1 \mathrm{~A}$, upper panel; compare lanes 1 and 4). Exposing cells to the inhibitor in a hypoxic environment resulted in an additional threefold increase in preproET-1 mRNA (lane 3) above that induced either by hypoxia alone (lane 1 ) or by normoxia plus L-NNA (lane 4). Thus, the basal levels of preproET-1 transcripts in endothelial cells appear to be regulated by endogenously produced NO. The same blot was stripped and reprobed with a cDNA probe for PDGF-B. As was the case with ET-1, PDGF-B mRNA levels were elevated at least twofold at a $21 \%$ oxygen environment in the presence of L-NNA (Fig. $1 \mathrm{~A}$, lower panel, lane 4 ) above $21 \%$ oxygen alone (lane 2 ). Hypoxia had a further two- to threefold increase in PDGF-B mRNA when cells were cultured along with L-NNA (lane 3 ) than either hypoxia alone (lane 1) or normoxia + L-NNA (lane 4). Thus, similar to its effects on ET-1, inhibition of NO synthesis elevated basal and hypoxia-induced mRNA levels of the PDGF-B gene in human endothelial cells.

$N O$ regulates the rate of $E T-1$ and $P D G F-B$ gene transcription. To elucidate mechanisms by which NO regulates the production of ET-1 and PDGF-B, nuclear run-off analysis was performed. Transcriptional rates were determined after $48 \mathrm{~h}$ of exposure of cells to normoxia $\left(21 \% \mathrm{O}_{2}\right)$ with or without 2.5 mM L-NNA. The transcriptional rate of another gene, bFGF, was analyzed for comparison (Fig. $1 B$ ). Compared to the transcriptional rate of preproET-1 in the control cells, there was a fourfold increase in preproET-1 gene transcription in cells treated with L-NNA. In the case of PDGF-B, the inhibitor of NO synthesis induced the rate of transcription of this gene twofold above control. In contrast, the transcriptional rate of the bFGF gene was similar in the presence or absence of this inhibitor.

NO suppresses the hypoxia-induced increases in preproET1 and PDGF-B $m R N A$. Cultures of HUVE were exposed to a hypoxic atmosphere with $\mathrm{PO}_{2}=20 \mathrm{~mm} \mathrm{Hg}(0 \%$ oxygen $)$ or to a normoxic atmosphere with a $\mathrm{PO}_{2}=150 \mathrm{mmHg}$ ( $21 \%$ oxygen ) for $24 \mathrm{~h}$. Northern blot analysis of endothelial cell RNA showed a consistent fourfold increase in steady-state preproET-1 mRNA levels in cells exposed to a hypoxic environ- 
A

OXYGEN $1 \% 21 \% 1 \% 21 \%$

L-NNA $\quad-\quad++$

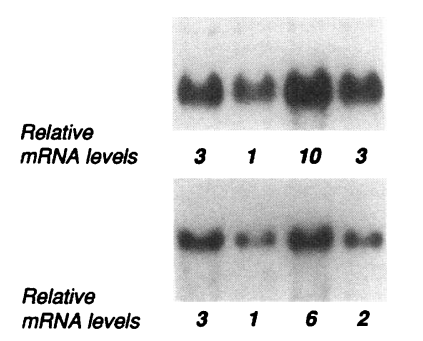

ET-1

PDGF-B
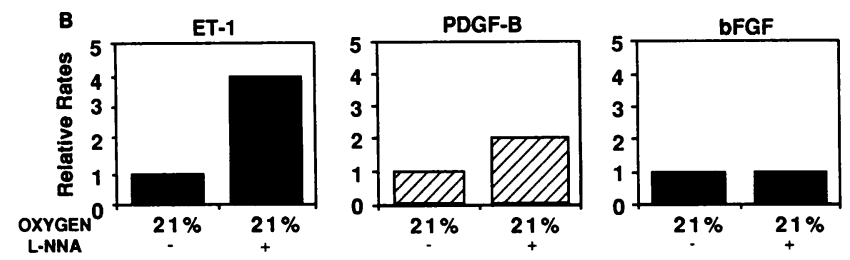

Figure 1. Effects of endogenous NO production on ET-1 and PDGF$B$ transcripts in HUVE. $(A)$ Inhibitors of NO synthesis increase preproET-1 and PDGF-B mRNA levels. Early passage HUVE from different donors were grown in $15-\mathrm{cm}$ diameter tissue culture plates containing $17 \mathrm{ml}$ of culture media. At confluence, the cells were exposed for $48 \mathrm{~h}$ to hypoxia (lanes 1 and 3 ) or normoxia alone (lanes 2 and 4 ) and in the presence (lanes 3 and 4 ) or absence (lanes 1 and 2) of $2.5 \mathrm{mM}$ L-NNA, and total cellular RNA was isolated by the method of Chirgwin et al. (15). $15 \mu \mathrm{g}$ of total RNA per lane was separated on $1 \%$ agarose gel containing formaldehyde and transferred to nitrocellulose filters. A ${ }^{32} \mathrm{P}$-labeled c-DNA probe for human preproET-1 was hybridized with the RNA and the blot was washed at high stringency. Autoradiography was performed and the bands were quantified using a densitometer. The filter was stripped and rehybridized with a probe for PDGF-B and then with a probe for $\beta$-actin to normalize for RNA loaded. Relative mRNA values are derived from a densitometric analysis of the amount of preproET-1 or PDGF-B transcripts expressed relative to control levels (normoxia) and corrected for the amount of actin transcripts per lane. Representative values are shown from at least five independent experiments. $(B)$ Inhibitors of NO synthesis increase preproET-1 and PDGF-B gene transcription. Endothelial cells at confluence were exposed for $48 \mathrm{~h}$ to a $21 \%$ oxygen environment in the presence or absence of $2.5 \mathrm{mM}$ L-NNA. Nuclei were isolated at the end and nuclear run-off analysis was performed in the presence of $\alpha-{ }^{32} \mathrm{P}$-UTP. Equal amounts of ${ }^{32} \mathrm{P}$ labeled, in vitro transcribed RNA was hybridized to denatured cDNA for the ET-1, PDGF-B, and bFGF genes. Relative rates of transcription between the two conditions are shown for each gene.

ment (Fig. 2 A, solid bars) compared to the transcript levels in cells maintained in a $21 \%$ oxygen environment. In contrast, there was no change over control levels in preproET-1 mRNA in cells exposed to a hypoxic environment while in the presence of $1 \mathrm{mM} \mathrm{SNP}$ whose biological activity is due to NO release. Cells exposed to $21 \%$ oxygen environment with SNP accumulated $30-40 \%$ less amounts of preproET-1 mRNA compared to controls at $21 \%$ oxygen alone. SNP also suppressed the hypoxia-induced transcript levels of PDGF-B at $24 \mathrm{~h}$. When the same blot was stripped and reprobed with a cDNA probe for PDGF-B, PDGF-B mRNA levels were found to be increased threefold in hypoxic compared to normoxic environments while SNP blocked these hypoxia-induced increases (Fig. $2 \mathrm{~A}$, hatched bars). Levels of actin mRNA were unaffected by oxy-

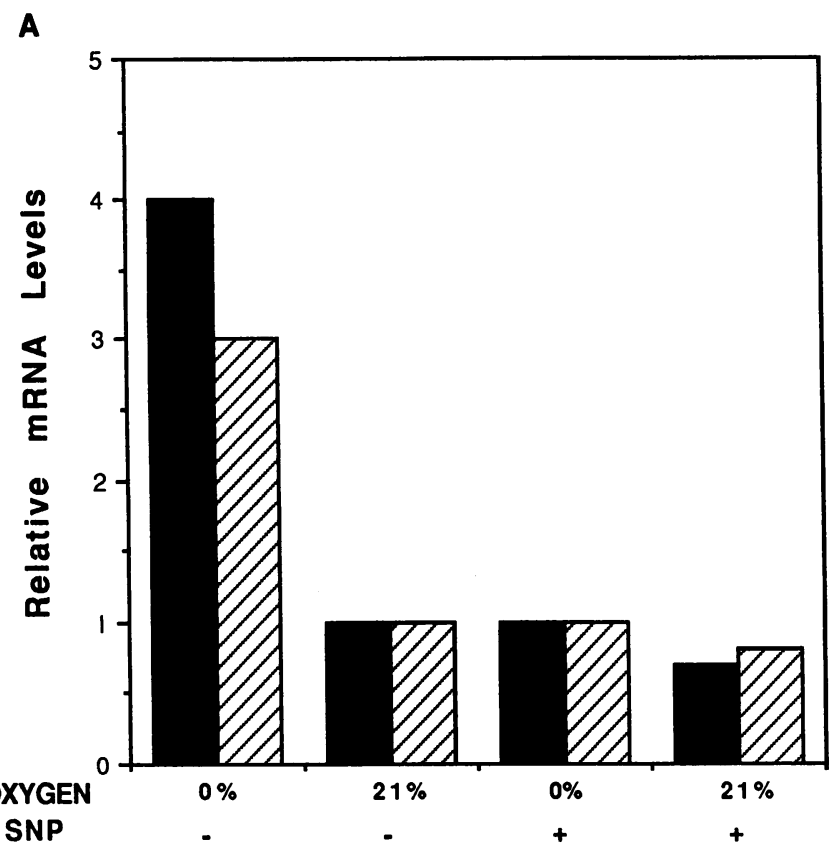

B

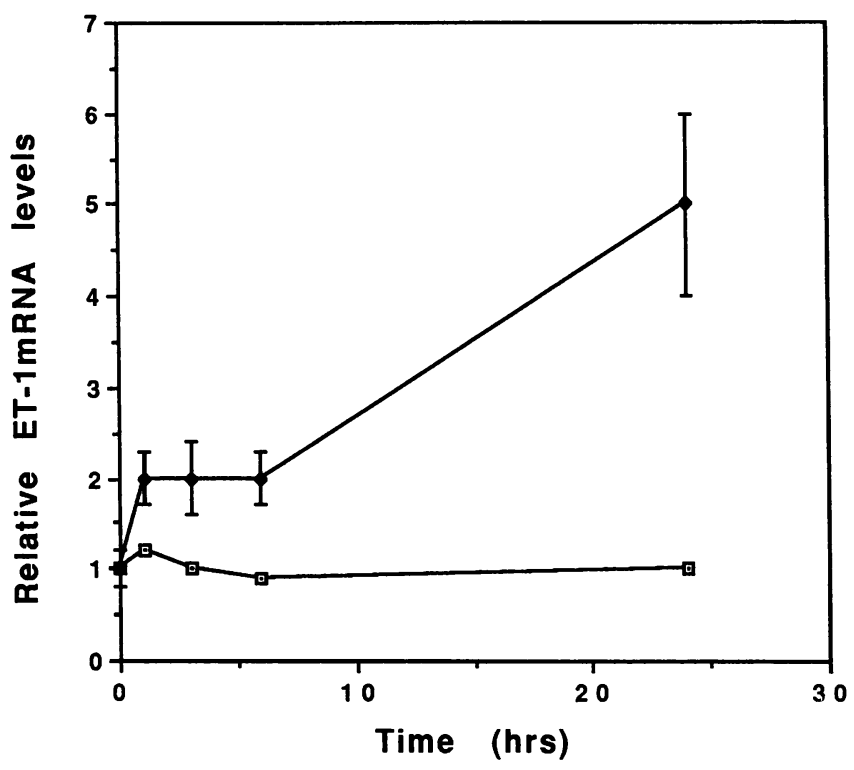

Figure 2. Effects of SNP on ET-1 and PDGF-B mRNA. ( $A$ ) NO suppresses the hypoxia-induced increases in ET-1 and PDGF-B mRNA. Endothelial cells at confluence were exposed to 0 or $21 \%$ oxygen environment in the presence or absence of $1 \mathrm{mM} \mathrm{SNP}$ for $24 \mathrm{~h}$. RNA was isolated as in Fig. 1, and Northern analysis was performed. The relative mRNA levels for preproET-1 (solid bars) and PDGF-B ( hatched bars) normalized to actin mRNA are shown for the various conditions. $0 \% \mathrm{O}_{2}$ without SNP was statistically different from all other conditions which were not different from one another. $(B)$ Time course of NO suppression of endothelin induction by hypoxia. Total RNA was isolated after endothelial cells reached confluence following $0,1,3,6$, and $24 \mathrm{~h}$ of hypoxia ( $0 \%$ oxygen environment) in the presence or absence of $1 \mathrm{mM}$ SNP. The preproET-1 mRNA levels are plotted against time of exposure to hypoxia with levels at the $0 \mathrm{~h}$ point arbitrarily set to 1 . The $\mathrm{Po}_{2}$ measured in the media reached a nadir of $20 \mathrm{mmHg}$ after $12 \mathrm{~h}$. It ranged between 80 and $60 \mathrm{mmHg}$ for the first $6 \mathrm{~h}$. This represents the sum of three independent experiments. 
gen tension or by SNP and are used to normalize for RNA loaded.

The time course of the blocking activity of SNP on hypoxia-induced preproET-1 mRNA expression was then examined. Hypoxia induced preproET-1 transcripts within $1 \mathrm{~h}$, but this induction was completely abrogated in the presence of SNP and no induction was seen even after $24 \mathrm{~h}$ of hypoxia (Fig. $1 \mathrm{~B})$. In the case of PDGF-B, SNP inhibited the hypoxia-induced increases in mRNA after $24 \mathrm{~h}$ (data not shown), the minimum time required for hypoxia to increase the transcriptional rate of this gene (13).

$N O$-regulated secretion of ET-1. To determine whether the changes in preproET-1 mRNA levels resulted in changes in ET-1 protein secretion, a radioimmunoassay was used to quantify the ET-1 secreted by endothelial cells. The conditioned media were assayed for ET-1 reactivity as described in Methods, after exposing endothelial cells to hypoxia $\left(0 \% \mathrm{O}_{2}\right)$ or normoxia $\left(21 \% \mathrm{O}_{2}\right)$ in the presence or absence of SNP or L-NNA for $24 \mathrm{~h}$. Using a radiobinding assay, we have previously reported a four- to eightfold increase in ET-1 secretion by endothelial cells exposed to hypoxia compared to normoxia (12). With the radioimmunoassay used here we detected higher baseline amounts of ET-1 at $21 \% \mathrm{O}_{2}$ environment than were detected with the radiobinding assay. Hypoxia resulted in a twoto threefold further increased secretion of ET-1 by endothelial cells (Fig. 3, column 1 versus column 2). However, cells exposed to a hypoxic environment in the presence of SNP demonstrated no increase in ET-1, and secreted amounts of ET-1 equal or lower than cells exposed to a $21 \% \mathrm{O}_{2}$ environment (column 3 versus column 2).SNP had no effect on the baseline

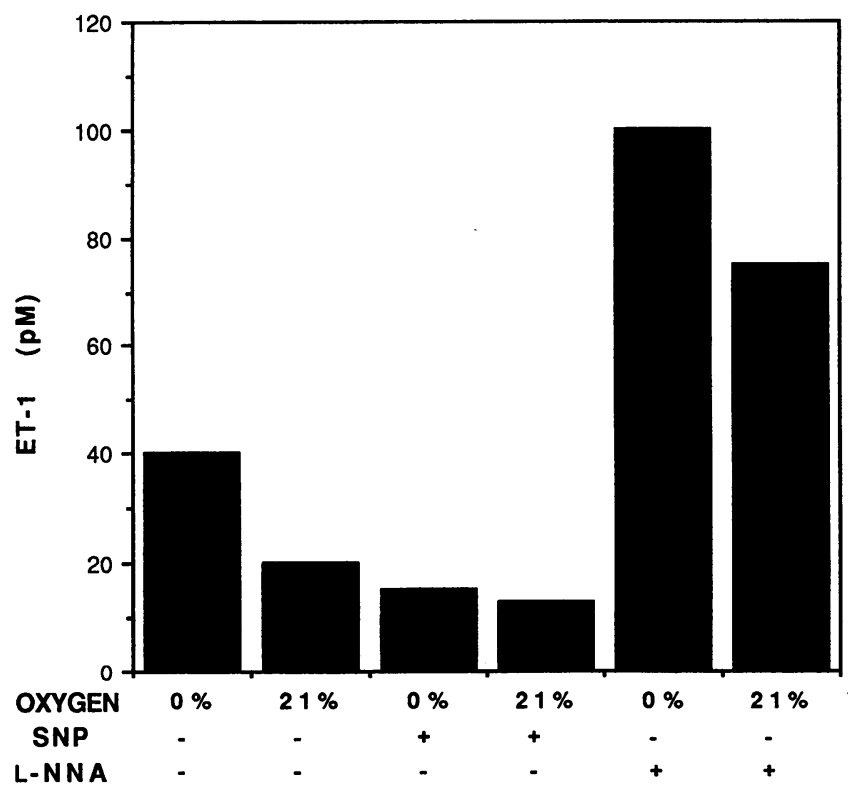

Figure 3. NO suppresses ET-1 secretion from cultured endothelial cells. Media were conditioned by endothelial cells for $24 \mathrm{~h}$ under normoxic $(21 \%)$ or hypoxic conditions $\left(21 \% \mathrm{O}_{2}+\mathrm{SNP}\right)$; in the presence or absence of SNP or L-NNA. The total amount of ET-1 secreted was quantified with a radioimmunoassay and normalized to total cellular protein. Recovery of ET-1 was $\geq 90 \%$. Inter- and intraassay variability were 12 and $6 \%$, respectively. ET-1 production is shown as ET-1 concentration in $3 \mathrm{ml}$ of medium produced per 24 $h$. The data shown are the sum of three independent experiments. secretion of ET-1 at $21 \% \mathrm{O}_{2}$ environment (column 4). In contrast, L-NNA increased the normoxic and hypoxic amounts of ET-1 at least fourfold above control (columns 5 and 6 versus 2).

Carbon monoxide (CO) mimics the effects of NO on PDGF$B$ and ET-1 gene expression. We have proposed that endothelial cells may sense oxygen levels via a heme-containing protein (12) which attains a "relaxed" configuration when bound with oxygen or a "tense" configuration when not bound. The tense configuration would result in increased gene expression of the vasoconstrictors ET-1 and PDGF-B. Similar mechanisms have been proposed in the regulation of the erythropoietin gene by hypoxia (18). Like oxygen, $\mathrm{CO}$ and $\mathrm{NO}$ are both bound by heme-containing proteins. We therefore tested the hypothesis that $\mathrm{CO}$ would have similar effects to those of $\mathrm{NO}$ and oxygen on the expression of the PDGF-B and ET-1 genes. Endothelial cells were exposed to hypoxic, normoxic, or hypoxic/10\% CO environments for $3 \mathrm{~d}$ and ET-1 and PDGF-B mRNA levels were determined (Fig. 4). Roughly fivefold greater ET-1 transcript levels accumulated in endothelial cells exposed to the hypoxic $\left(0 \% \mathrm{O}_{2}\right)$ environment for this time period compared to levels in normoxia (Fig. 4, solid bars). In contrast, cells exposed to $10 \% \mathrm{CO}$ in $0 \% \mathrm{O}_{2}$ expressed only low levels of ET-1 mRNA. These mRNA levels were similar to those in normoxia and markedly less than the levels in hypoxia alone. As was the case with ET-1, PDGF-B mRNA was also expressed at low levels when cells were exposed to $10 \% \mathrm{CO}$ in a hypoxic environment comparable to those at $21 \% \mathrm{O}_{2}$ (Fig. 4, hatched bars). At $0 \% \mathrm{O}_{2}$ alone, PDGF-B mRNA levels were tenfold greater than those in cells maintained in $21 \% \mathrm{O}_{2}$ environment. In contrast, actin mRNA levels are not affected by the presence of oxygen or $\mathrm{CO}$.

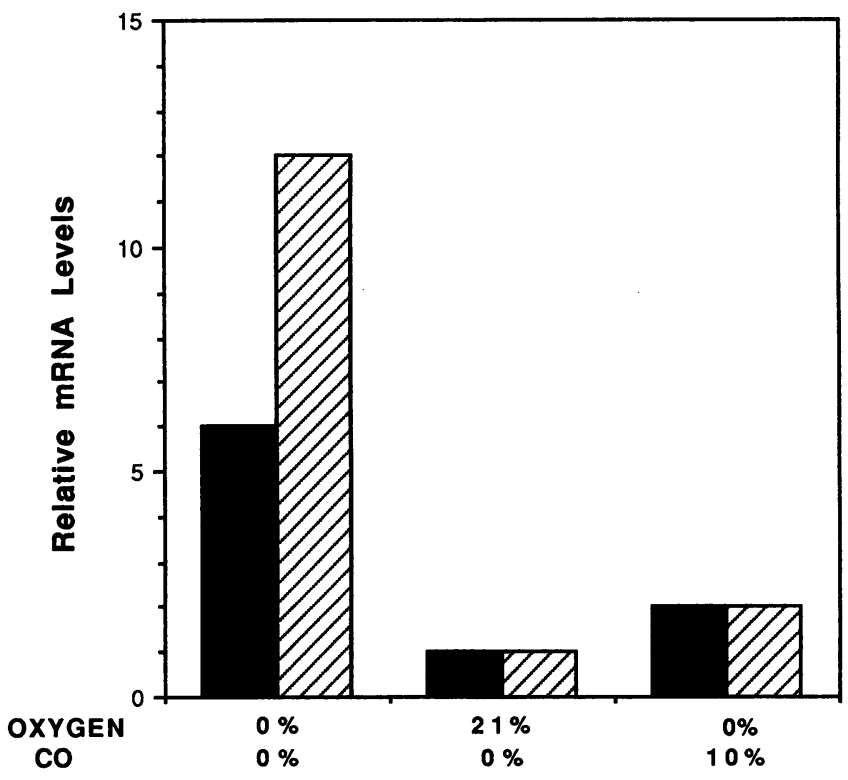

Figure 4. CO inhibits the hypoxia-induced increases in PDGF-B and ET-1 mRNA. Endothelial cells were exposed to hypoxic $\left(0 \% \mathrm{O}_{2}\right)$, normoxic $\left(21 \% \mathrm{O}_{2}\right)$, or $0 \% \mathrm{O}_{2}+10 \% \mathrm{CO}$ environments for $3 \mathrm{~d}$, RNA was isolated, and Northern analysis performed. The blot was probed with a CDNA probe for ET-1 and then stripped and reprobed with PDGF-B and $\beta$-actin. Relative mRNA levels for ET-1 (solid bars) and PDGF-B (hatched bars) are shown normalized to actin. 


\section{Discussion}

Hypoxia in vivo is associated with constriction of the pulmonary vasculature. The mechanism by which hypoxia might mediate pulmonary vasoconstriction is not known, but based on its location the endothelial cell layer lining of blood vessels is suspected to play a key role. Changes in oxygen tension in the blood stream are sensed by the endothelial cells which may respond by releasing a number of different vasoactive agents including ET-1 (12), PDGF $(2,13)$, or other unknown agents (19) that serve to modify the contractile and proliferative state of the underlying smooth muscle cells. Endothelial cells are also a source of NO, an important endothelial-derived relaxing factor. A role for NO in regulating the pulmonary blood vessel tone in response to hypoxia is not clearly defined but it is reasonable to suspect that local levels of NO might modify the hypoxic vasoconstrictive responses (20-22). Endothelial cells, therefore, may serve to regulate local tone by releasing vasoconstrictive or vasodilating agents in response to varying stimuli.

We have previously reported that compared with normoxia, exposure of cultured endothelial cells to hypoxia $\left(\mathrm{PO}_{2}\right.$ $=20-30$ Torr) results in four- to eightfold increases in ET-1 gene expression and secretion. In this study we show that this hypoxic response can be abolished if NO is delivered exogenously by SNP. Within $1 \mathrm{~h}$ of hypoxic exposure, the earliest time we are able to document increases in ET-1 by hypoxia (12), SNP inhibited the induction of ET-1 expression. Conversely, inhibition of NO production with a competitive inhibitor of NO synthase, such as L-NNA, increased the baseline production of ET-1 protein and mRNA threefold in a $21 \%$ oxygen environment. There was a further threefold increment in ET-1 if these same cells were exposed to a hypoxic environment in the presence of the inhibitor. These changes in ET-1 production as a function of NO occurred at the level of gene transcription and resulted in corresponding changes of the preproET-1 transcript levels.

Similar effects on the PDGF-B gene were seen by modulating levels of NO in the culture conditions as above, suggesting a common mechanism of action by NO on the hypoxic regulation of genes encoding these two vasoconstrictors. Yokokawa et al. (23) reported that $N^{\mathrm{G}}$-monomethyl L-arginine (another inhibitor of NO synthesis) enhanced the endothelin-3-induced ET-1 production by HUVE. Boulanger and Lüscher (24) have reported that the release of endothelin from the intact porcine aorta is inhibited by endothelium-derived NO. In their system, the basal release of endothelin was unaffected by NOS inhibitors and only the thrombin or calcium ionophore A23187-induced release of endothelin was affected by elevated levels of NO. In our human endothelial culture system, however, both basal ET-1 gene expression and release of endothelin were substantially increased by inhibition of the endothelial-derived NO synthesis and these were even further increased in hypoxia. In agreement with our results, Saijonmaa et al. also reported that SNP reduced the basal production of endothelin by these same cells (25).

Work by Moncada et al. has suggested that endogenous levels of NO maintain the vasculature in a dilated state (6). Intravenous injections of $N^{\mathrm{G}}$-monomethyl-L-arginine into various species as well as humans caused a substantial and immediate rise in blood pressure (6). Chang et al. reported that basal NO release plays an important role in maintaining the low vascular tone in the intact umbilical-placental circulation (26). These data suggest that baseline constitutive levels of NO may play a direct role in the maintenance of vascular relaxation. In addition, NO may enhance vasodilation by interfering with the baseline expression of vasoconstrictors and thus mimic the actions of oxygen on ET-1 and PDGF-B gene regulation.

One possible common mechanism of signal transduction of oxygen and NO could be a heme-binding protein that binds these ligands and attains a relaxed form (bound state) or a tense configuration in the unbound state. In this manner, NO could evoke potentially similar intracellular events to those induced by oxygen, leading to the transcriptional regulation of the ET-1 and PDGF genes. Indeed, any molecule bound by heme proteins in this same manner would be predicted to lead to similar regulatory events. We formally tested this hypothesis by exposing cells to $\mathrm{CO}$, another known ligand for heme. We found that in the presence of CO both the ET-1 and PDGF-B genes continued to be expressed at only low levels, as if in a normoxic environment, despite the absence of oxygen. Similar findings using $\mathrm{CO}$ have been reported for the erythropoietin gene, which is also regulated by hypoxia (18). In addition, $\mathrm{CO}$ has recently been reported to activate guanylate cyclase and to be a regulator of cGMP very much like NO (27). Similar to $\mathrm{NO}$, therefore, $\mathrm{CO}$ can serve as a smooth muscle cell dilator regulating blood vessel tone in the vasculature (27).

Since NO and CO were found to suppress the hypoxic increases in vasoconstrictor production and since they both activate guanylate cyclase, we tested the hypothesis that elevated cGMP levels may also downregulate ET-1 and PDGF-B gene expression. In the presence of methylene blue, an inhibitor of guanylate cyclase, the basal and hypoxic transcript levels of ET-1 and PDGF-B were slightly elevated. In contrast, 8bromo-cGMP addition had no effect on ET-1 and PDGF-B expression providing more evidence for an alternative mechanism of hypoxic signal transduction (e.g., via a heme-containing sensor).

Whether or not the NO and oxygen signals are transduced intracellularly via common pathways, both NO and oxygen do have similar vasodilating effects on the pulmonary vascular tone. NO exerts its vasodilating effect in at least two ways: via previously described direct effects on the baseline tone of vascular smooth muscle; and, according to our findings, indirectly by inhibiting endothelial production of the potent vasoconstrictors, ET-1 and PDGF-B.

\section{Acknowledgments}

We thank Drs. Merton Bernfield and Patricia D'Amore for critical review of the manuscript and Kelly Ames for her expert secretarial assistance.

Dr. Faller was supported by research grants from the National Institutes of Health and The Council for Tobacco Research. Dr. Kourembanas was supported by grants from the Charles H. Hood Foundation and the National Institutes of Health (grant HL-02394 and SCOR 1P05HL-46491).

\section{References}

1. Yanagisawa, M., H. Kurihawa, S. Kimura, Y. Tomobe, M. Kobayashi, Y. Mitsui, Y. Yazaki, K. Goto, and T. Masaki. 1988. A novel potent vasoconstrictor peptide produced by vascular endothelial cells. Nature (Lond.). 332:411-415. 
2. Bowen-Pope, D. F., C. E. Hart, and R. A. Seifert. 1989. Sera and conditioned media contain different isoforms of platelet-derived growth factor (PDGF) which bind to different classes of PDGF receptor. J. Biol. Chem. 264:2502-2508.

3. Palmer, R. M., A. G. Ferrige, and S. Moncada. 1987. Nitric oxide release accounts for the biological activity of endothelium-derived relaxing factor. $\mathrm{Na}$ ture (Lond.). 327:524-526.

4. Furchgott, R. F., and J. V. Zawadzki. 1980. The obligatory role of endothelial cells in the relaxation of arterial smooth muscle by acetylcholine. Nature (Lond.). 288:373-376.

5. Palmer, R. M., D. S. Ashton, and S. Moncada. 1988. Vascular endothelial cells synthesize nitric oxide from L-arginine. Nature (Lond.). 333:664-666.

6. Vallance, P., J. Collier, and S. Moncada. 1989. Effects of endothelium-derived nitric oxide on peripheral arteriolar tone in man. Lancet. ii:997-1000.

7. Lerman, A., F. L. Hildebrand, Jr., K. B. Margulies, B. O’Murchu, M. A. Perrella, D. M. Heublein, T. R. Schwab, and J. C. Burnett, Jr. 1990. Endothelin: new cardiovascular regulatory peptide. Mayo Clin. Proc. 65:1441-1455.

8. Moon, D. G., M. J. Horgan, T. T. Andersen, S. R. Krystek, Jr., J. W. Fenton II, and A. B. Malik. 1989. Endothelin-like pulmonary vasoconstrictor peptide release by $\alpha$-thrombin. Proc. Natl. Acad. Sci. USA. 86:9529-9533.

9. Miyauchi, T., M. Yanagisawa, T. Tomizawa, Y. Sugishata, N. Suzuki, M Fujino, R. Ajisaka, K. Goto, and T. Masaki. 1989. Increased plasma concentrations of endothelin-1 and big endothelin-1 in acute myocardial infarction (letter to the editor). Lancet. ii:53-54.

10. King, A. J., and B. M. Brenner. 1991. Endothelium-derived vasoactive factors and the renal vasculature. Am. J. Physiol. 260:R652-R663.

11. Stewart, D. J., R. Levy, P. Cernacek, and D. Langleben. 1991. Increased plasma endothelin-1 in pulmonary hypertension-marker or mediator of disease? Ann. Intern. Med. 114:464-469.

12. Kourembanas, S., P. A. Marsden, L. P. McQuillan, and D. V. Faller. 1991. Hypoxia induces endothelin gene expression and secretion in cultured human endothelium. J. Clin. Invest. 88:1054-1057.

13. Kourembanas, S., R. L. Hannan, and D. V. Faller. 1990. Oxygen tension regulates the expression of the platelet-derived growth factor-B chain gene in human endothelial cells. J. Clin. Invest. 86:670-674.

14. Sachinidis, A., R. Locher, J. Hoppe, and W. Vetter. 1990. The plateletderived growth factor isomers, PDGF-AA, PDGF-AB and PDGF-BB, induce contraction of vascular smooth muscle cells by different intracellular mechanisms. FEBS (Fed. Eur. Biochem. Soc.) J. 275:95-98.

15. Chirgwin, J. M., A. E. Przybyla, R. J. MacDonald, and W. J. Rutter. 1979.
Isolation of biologically active ribonucleic acid from sources enriched in ribonuclease. Biochemistry. 18:5294-5299.

16. Itoh, Y., M. Yanagisawa, S. Ohkubo, C. Kimura, T. Kosaka, A. Inoue, N. Ishida, Y. Mitsui, H. Onda, M. Fujino, and T. Masaki. 1988. Cloning and sequence analysis of cDNA encoding the precursor of a human endothelium-derived vasoconstrictor peptide, endothelin: identity of human and porcine endothelin. FEBS (Fed. Eur. Biochem. Soc.) Lett. 231:440-444.

17. Gelmann, E. P., E. Petri, A. Cetta, and F. Wong-Staal. 1982. Deletions of specific regions of the simian sarcoma-associated virus genome are found in defective viruses and in the simian sarcoma virus. J. Virol. 41:593-604.

18. Goldberg, M. A., S. P. Dunning, and H. F. Bunn. 1988. Regulation of the erythropoietin gene: evidence that the oxygen sensor is a heme protein. Science (Wash. DC). 242:1412-1415.

19. Vender, R. L., D. R. Clemmons, L. Kwock, and M. Friedman. 1987. Reduced oxygen tension induces pulmonary endothelium to release a pulmonary smooth muscle cell mitogen(s). Am. Rev. Respir. Dis. 135:622-627.

20. Frostell, C., M. D. Fratacci, J. C. Wain, R. Jones, and W. M. Zapol. 1991. Inhaled nitric oxide. A selective pulmonary vasodilator reversing hypoxic pulmonary vasoconstriction. Circulation. 83:2038-2047.

21. Ogata, M., M. Ohe, D. Katayose, and T. Takishima. 1992. Modulatory role of EDRF in hypoxic contraction of isolated porcine pulmonary arteries. Am. J. Physiol. 262:H691-H697.

22. Adnot, S., B. Raffestin, S. Eddahibi, P. Braquet, and P. E. Chabrier. 1991 Loss of endothelium-dependent relaxant activity in the pulmonary circulation of rats exposed to chronic hypoxia. J. Clin. Invest. 87:155-162.

23. Yokokawa, K., M. Kohno, K. Yasunari, K. Murakawa, and T. Takeda. 1991. Endothelin-3 regulates endothelin-1 production in cultured human endothelial cells. Hypertension (Dallas). 18:304-315.

24. Boulanger, C., and T. F. Lüscher. 1990. Release of endothelin from the porcine aorta. Inhibition by endothelium-derived nitric oxide. J. Clin. Invest. 85:587-590.

25. Saijonmaa, O., A. Ristimäki, and F. Fyhrquist. 1990. Atrial natriuretic peptide, nitroglycerine, and nitroprusside reduce basal and stimulated endothelin production from cultured endothelial cells. Biochem. Biophys. Res. Commun. 173:514-520.

26. Chang, J.-K., C. Roman, and M. A. Heymann. 1992. Effect of endothelium-derived relaxing factor inhibition on the umbilical-placental circulation in fetal lambs in utero. Am. J. Obstet. Gynecol. 166:727-734.

27. Verma, A., D. J. Hirsch, C. E. Glatt, G. V. Ronnett, and S. H. Snyder 1993. Carbon monoxide: a putative neural messenger. Science (Wash. DC) 259:381-384. 